\title{
Müfredat Dışı Okul İ̧̧i Boş Zaman Aktiviteleri Katı̀ımının 10-14 Yaş Ortaokul Öğrencilerin Şiddet Eğilimleri ve Sosyal Bağlılık Düzeyleri Üzerine Etkisinin İncelenmesi
}

\author{
Muhammet KOCAMAZ ${ }^{1}$ D, Süleyman MUNUSTURLAR ${ }^{2 *}$ \\ ${ }^{1}$ Anadolu Üniversitesi, Sosyal Bilimler Enstitüsü, Eskişehir. \\ ${ }^{2}$ Eskişehir Teknik Üniversitesi, Spor Bilimleri Fakültesi, Eskişehir.
}

Orijinal Makale

Gönderi Tarihi: 08.07.2021
Kabul Tarihi: 02.12.2021
DOI:10.25307/jssr.966329

Online Yayın Tarihi: 31.12 .2021

\section{Öz}

Bu çalışmanın amacı; müfredat dışı okul içi rekreasyonel aktivitelere katılan öğrencilerin şiddet eğilimlerinin ve sosyal bağl1lık düzeylerinin incelenmesidir. Araştırma verileri Şanlıurfa ilinden kolayda örneklem yöntemi ile toplanmıştır. Araştırma katılımcılarını Milli Eğitim Bakanlığına bağlı bir ortaokulda eğitim görmekte olan 150 birey oluşturmaktadır.Örneklem grubunda bulunan bireylerden 60 kişi haftalık 4 saat beden eğitimi dersinin yanında okul futbol, futsal takımlarında yer almasına bağlı olarak haftalık 6 saat antrenmana katılan bireyler olduğu için aktif spor yapan öğrenci grubu olarak seçilmiş, 90 kişi ise haftalık 4 saat beden eğitimi dersi dıșında herhangi bir sportif faaliyete katılmayan, aktif spor yaşantısı olmayan öğrencilerden seçilmiştir. Araştırmada; araştırmacı tarafından oluşturulan Kişisel Bilgi Formu, Şiddet Eğilimi Ölçeği (ŞEÖ) ve Sosyal Bağlılık Ölçeği (SBÖ) kullanılmıştır. Verilerin analizinde betimsel istatistiklerin yanı sıra değişken sayısına bağlı olarak Bağımsız Gruplarda T Test uygulanmıştır. İstatistiksel analiz sonuçlarına göre; rekreatif etkinliklere katılıma göre öğrencilerin şiddet eğilimi ve sosyal bağlılık düzeylerinde anlamlı farklılık saptanmıştır $(\mathrm{p}<0.05)$. Ayrıca benzer şekilde öğrencilerin şiddet eğilimi ve sosyal bağlılık düzeylerinde cinsiyet değişkenine göre anlamlı farklılığa ulaşılmıştır $(p<0.05)$. Anahtar kelimeler: Boş zaman, Fiziksel aktivite, Şiddet eğilimi, Sosyal bağlılık

\section{Examination of the Effect of Participation in Extra-Curriculum In-School Leisure Activities on the Violence Tendency and Social Commitment Levels of 10-14 Years Old Secondary School Students}

\begin{abstract}
This study aimed to analyse the violent tendencies and social connectedness levels of students who participate in extracurricular in-school leisure activities. Data were obtained using a convenience sampling method from the city of Şanlıurfa. The participants were included 150 students who are attending a secondary school, which is governed by the Republic of Turkey Ministry of National Education. 60 students of the sample group were chosen to be the active group who did sports actively because they participated in a weekly 6-hour training as they were members of the school soccer team, in addition to a weekly 4-hour PE class. 90 people were chosen from the students who did not do any sports activities except the weekly 4hour PE class. In the research, personal information form, which is created by the researcher, Violence Tendency Scale and Social Connectedness Scale were used. In data analysis, in addition to descriptive statistics, the Independent Samples t-Test was used. According to statistical results, statistically significant difference was found in violent tendencies and social connectedness levels of students, in accordance with participation in leisure activities $(\mathrm{p}<0.05)$. Similarly, statistical significance was determined in violent tendencies and social connectedness levels of students in terms of gender $(p<0.05)$. Keywords: Leisure, Physcal activity, Violent tendencies, Social connectedness
\end{abstract}

*Bu çalışma 7-10 Kasım 2020 tarihinde düzenlenen 18. Uluslararası Spor Bilimleri Kongresinde sözel bildiri olarak sunulmuştur.

${ }^{*}$ Sorumlu Yazar: Muhammet KOCAMAZ, E-posta: muhammetkocamaz42@gmail.com 


\section{GíRiș}

Kişinin kendisi ve başkaları için görev sayılabilecek tüm mecburiyetlerinden uzak kaldığı ve seçeceği faaliyetlerde katılımın gönüllülüğün esas alındığı zaman dilimi olarak açıklanan boş zaman kavramı, evrensel bir kavram olmakla birlikte İngilizce karşılı̆̆1 "leisure" olarak açıklanmaktadır (Hacıoğlu, Gökdeniz, Dinç, 2003). Kişinin boş zamanlarında katılım sağlayacağı etkinlikleri seçiminde gönüllülüğün olması ve katılım sağlamak istediği boş zaman faaliyeti ile karşılıklı ritmin ve uyumluluğun sağlanmasında gerek içsel gerek dışsal olarak ayrılan boş zaman motivasyonu oldukça önemlidir.

Ülkemizde her kademede eğitimine devam etmekte olan bireyler günün saatinin büyük bir kısmını okulda geçirmektedir. Sürenin çok olması öğrencilerde istendik davranışların yanı sıra gizil öğrenme yöntemi ile istenmedik kazanımlara da neden olabilmektedir. İki yönlü değerlendirilme yapıldığında bireyler için okul içerisinde geçirilen boş zaman diliminin olumlu ve olumsuz yönleri bulunmaktadır. Bireyler okul içerisinde yaptıkları boş zaman aktiviteleri sayesinde diğer bireyler arası grup dinamiği oluşturup sosyal bağlılık ve aidiyet duygularında gelişim sağlayabilir. Bunun yanısıra okul içi boş zaman aktivitelerinin bireyler tarafından bilinçli bir şekilde kullanılmaması şiddet eğilimlerinde artış sağlayıp olumsuz sonuçlar da doğurabilir (Gözütök, 2008). Bireylerin okul içerisinde kısıtlı bir zaman dilimi olarak görülen boş zamanlarını fiziksel aktivite ile sağlıklı bir şekilde değerlendirmelerinin eğitimine önem verilmesinin olumlu sonuçlar doğuracağı aşikardır. Okul içerisinde geçirilen bu süre içerisinde beden eğitimi dersi dışında yapılan ekstra sportif faaliyetler öğrencilerin aktif spor yaşantılarına katkı sağlamaktadır. Çocukların okul saatleri içerisinde boş zaman etkinliklerini yapabileceği çeşitli zaman dilimleri (tenefüs, öğle arası vb.) bulunmasına rağmen okul içi zamanının büyük kısmını durağan (sedanter) davranış olarak geçirmektedir (Burns, Brusseau ve Hannon, 2015). Alan yazında gerçekleştirilen farklı çalışmalardan ulaşılan sonuçlara göre beden eğitimi ve spor, serbest zaman etkinlikleri dersi, tenefüs saatleri gibi zaman dilimlerinin, gündelik fiziksel aktivite düzeyini üst seviyelere çıkarmak için öğrenciler için önemli bir avantaj olabileceğini söylemektedir (Mckenzie, Crespo, Baquero ve Elder, 2010).

Günümüzde okullarda önemli problem haline gelen ve gençler arasında maddi ve manevi zararlarla sonuçlanan kavgaların artışına dönük şiddet olayları medyada sürekli yer bulmaktadır. Ayrıca televizyonda fazla şiddet filmleri izlemenin gençlerde saldırganlık düzeyini arttırıcı davranışlara yol açtığı bilinmektedir (Avcı ve Güçray, 2010; Şahin, 1999). Üstün, Yılmaz ve Kırbaş'a (2007) göre eğitim kurumlarında meydana gelen şiddet olayları incelendiğinde özellikle iletişimin zayıf olduğu aile yapısı şiddete meyil verirken, akran grupları da saldırganlığı ortaya çıkaracak ve bunu uygulayabilecek ortamı hazırlamakta olduğunu belirtmiştir. Haskan ve Yıldırım (2014) yapmış oldukları çalışmada en sık karşılaşılan şiddet türlerinin karşı cinsle ilişkilerde yaşanan şiddet ve gençler arası anlaşmazlıklar sonucu başvurulan şiddet olduğunu ifade etmektedir. Nitekim okul içi şiddetin hızlı bir şekilde artmaya başladığı yapılan çalışmalarla ortaya konulmaya çalışılmıştır (Haskan, 2009; Tuzgöl, 2000; Üstün, Yılmaz ve Kırbaş, 2007). Bacıoğlu'na (2014) göre yetişen yeni nesli kötü alışkanlık, bağımlılık ve şiddet eğiliminden uzak tutmak adına sportif faaliyetlerin yapılması ve yaygınlaştırılması önem kazanmaktadır (Bacıŏlu, 2014). Yapılan bir çalışmada aktif olarak spor yapan öğrencilerin şiddet eğilimleri arasında anlamlı fark olmamasına rağmen 
aktif spora katılan bireylerin şiddet eğilimlerinin spor yapmayanlara göre daha düşük çıktığ1 belirlenmiştir (Aydın, Ersoy ve Aktaş, 2015).

Bireyin boş zaman aktivitelerine katılım sağlamasının sosyal alanda bir çok faydasının olduğu bilinmektedir. Buna bağlı olarak çocukların fiziksel aktivite düzeyinin takip edilmesi, toplum sağlığının bilişsel ve sosyal açıdan gelişim sağlaması için oldukça önemli bir değişkendir (Fairclough ve Ridgers, 2010). Toplumun temel yapı taşı olan çocuk yaştaki bireyler farklı günlerde, Intramural-extramural (okul içi- okul dışı) farklı zaman aralıklarında çeşitli boş zaman etkinlikleri yaparak günlük aktivite seviyelerini farklı seviyede yerine getirmekte ve gün içerisinde yaptıkları bu aktiviteler günlük aktivite seviyesinin takibi açısından önemli bir değişken olan adım sayısını etkileyebilmektedir (Fairclough ve Ridgers, 2010). Bu sebeple öğrencilerin fiziksel aktivite seviyelerini açığa çıkarabilmek için zaman aralıklarının ön planda tutulması genel anlamda önemlidir. Çünkü öğrencilerin gün içerisinde aktif ya da sedanter olarak geçirecekleri zaman dilimleri hakkında bilgi sahibi olunduğunda öğrenciler için hangi zaman dilimlerinin fiziksel olarak aktif zaman geçirebilineceği, hangi zaman aralıklarında sedanter davranış içerisinde bulunulacağı fiziksel aktivite seviyesi hakkında ya da fiziksel aktivite seviyesinin yükseltilmesinde önemli ipuçları verecektir. Okula devam etmekte olan çocuk yaştaki bireyler haftanın çoğu gününde, sahip oldukları zaman dilimlerinin yüksek orandaki kısmını okul içerisinde geçirdikleri için okul saatleri içinde bireyin attığı adım sayısının, gün boyunca atmış olduğu adım sayısını etkilediği bilinmektedir (Burns, Brusseau ve Hannon, 2015). Dolayısıyla okul içerisinde yapılan gerek müfredat içerisindeki derslerin gerekse müfredat dışı olarak yapılan okul sporları, egzersiz gibi aktivitelerin arttırılması ile çocukların hedeflenen aktivite seviyesine ulaşmasında okul içi boş zamanların oldukça önem taşıdığı yadsınamaz bir gerçektir (Burns, Brusseau ve Hannon, 2015). Fakat literatür incelendiğinde bireylerin okul içi bölümlerinde yararlanabileceği boş zaman aktiviteleri ve günlük enerji harcama miktarına bağlı olan fiziksel aktivite seviyesiyle alakalı çalışmalar bulunmakta (Taras, 2005; Troiano ve diğerleri, 2008; Trudeau ve Shephard, 2010) ancak nicelik olarak yeterli sayıda bilimsel çalışma bulunmamaktadır. Okul çağı bireyler için okul öncesinde ve sonrasında geçirilen zaman aralığında yapılan aktiviteler boş zaman aktiviteleri olarak değerlendirilmektedir. Çocuklar için okul içinde bulunan zamanların, enerji tüketimine bağlı gündelik fiziksel aktivite seviyesini arttırmada istatistiksel olarak önemli bir değişken olduğu farklı çalışmalardan anlaşılmaktadır (Beighle, Morgan, Le Masurier ve Pangrazi, 2006; Mota ve diğerleri, 2005). Literatür incelendiğinde son 10 yılda yapılan farklı çalışmalar sonucunda, okul içerisindeki boş zaman olarak değerlendirilen tenefüs aralarının günlük fiziksel aktivite seviyesinde anlamlı düzeyde artırdığı sonucuna ulaşılmıştır. Ancak ders arasındaki kısımlar ülkenin ders işleyiş, yönetmelik ve müfredatına göre farklılık gösterdiği için bu sürelerin fiziksel aktivite seviyesi üzerine etkisi de ülkeden ülkeye farklılık gösterebilmektedir (Burns, Brusseau ve Hannon, 2015). Müfredat diş1 yapılan boş zaman etkinlikleri fiziksel aktivite düzeyini arttırıp sosyal yönden okul sorunlarının azalması ve bireyler arasındaki ilişkilerin güçlenmesine katkı sağlayacağından, okullarda boş zaman etkinliklerinin artması okul öğrencileri arasında çeşitli yönlerden pozitif düzeyde etki sağlayacağı tahmin edilmektedir. Buradan hareketle; çalışmanın amacı müfredat dış1 okul içi rekreasyonel aktivitelere katılan öğrencilerin şiddet eğilimlerinin ve sosyal bağlılık düzeylerinin incelenmesidir. Bu doğrultuda; 
- Müfredat dışı boş zaman aktivitelere katılımının ortaokul öğrencilerinin şiddet eğilimi üzerine etkisi var midır?

- Müfredat dışı boş zaman aktiviteleri katılımının ortaokul öğrencilerinin sosyal bağlılık düzeyi üzerine etkisi var mıdır?

- Müfredat dışı boş zaman aktiviteleri katılan ortaokul öğrencilerinin şiddet eğilimi düzeyinde cinsiyete göre farklılık var midır?

- Müfredat dışı boş zaman aktiviteleri katılan ortaokul öğrencilerinin sosyal bağlılık düzeyinde cinsiyete göre farklılık var mıdır? sorularına cevap aranmıştır.

\section{YÖNTEM}

\section{Araştırma Modeli}

Nicel bir çalışma olan araştırmamızda tarama modeli kullanılmıştır. Bu çalışma ortaokul grubu öğrencilerin boş zaman aktivitelerine katılım durumuna göre şiddet eğilimi ve sosyal bağlılık düzeyleri üzerindeki değişimi görmek amacıyla evrenin tamamını temsil eden bir örneklem grubu üzerinde yürütülmüştür. Bu sebeple tarama modeli tercih edilmiştir. Bu modelin amacı evrenden alınacak örneklem üzerinde çeşitli bilimsel uygulamaların yapılacağı taramadır. Çok sayıda oluşan bir evrende, örneklemden hareketle evren üzerine kapasitel sonuçlara ulaşılmak istenir (Karasar, 2015).

\section{Araştırma Grubu}

Çalışma verilerine Şanlıurfa ilinden kolayda örneklem yöntemi uygulanarak ulaşılmıştır. Çalışma katılımcılarını Milli Eğitim Bakanlığına bağlı Şanlıurfanın Siverek ilçesinde bulunan bir ortaokulda 2020-2021 eğitim öğretim y1lında aktif olarak eğitim görmekte olan 152 birey oluşturmaktadır. Çalışmamız deneysel desene dışarıdan etki edecek faktörleri en aza indirebilmek maksadıyla tek okulda yürütülmüştür. Ayrıca okul seçimi yapılırken; boş zaman aktivitelerine katılım sağlayan bireyleri belirleyebilmek amacıyla aktif olarak boş zaman aktivitelerinin yapıldığı, okul sporlarına katılım sağlayıp düzenli antreman yapan okul tercih edilmiştir.

Örneklem grubunda bulunan bireylerden 58 kişi haftalık 4 saat beden eğitimi dersinin yanında okul futbol, futsal takımlarında yer almasına bağlı olarak haftalık 6 saat antremana katılan bireyler olduğu için aktif spor yapan öğrenci grubu olarak seçilmiş, 94 kişi ise haftalık 4 saat beden eğitimi dersi dişında herhangi bir sportif faaliyete katılmayan, aktif spor yaşantısı olmayan öğrencilerden seçilmiştir.

Tablo 1. Boş zaman aktivitesine katılım durumu

\begin{tabular}{llcc}
\hline Kişisel Bilgiler & Değișkenler & F & \% \\
\hline \multirow{2}{*}{ Müfredat Dışı Aktiviteye Katılan } & Kadın & 22 & 14,4 \\
& Erkek & 36 & 23,6 \\
& Toplam & 58 & 38 \\
\hline \multirow{2}{*}{ Müfredat Dışı Aktiviteye Katılmayan } & Kadın & 43 & 28,5 \\
& Erkek & 51 & 33,5 \\
& Toplam & 94 & 62 \\
\hline Toplam & & 152 & 100 \\
\hline
\end{tabular}

Araştırmaya katılan bireylerin cinsiyete göre dağılımları incelendiğinde müfredat dışı boş zaman aktivitesine katılan kadın \%14,4, müfredat dışı aktiviteye katılan erkek \%23,6, müfredat 
dışı aktiviteye katılmayan erkek \%33,5 iken aktiviteye katılmayan kadınların sayısı \%28,5 olduğu, genel toplamlar bazında bakıldığında çalışmaya katılan bireylerin \%42,9' unun kadın, \%57,1' inin erkek olduğu, müfredat dış1 etkinliklere katılım incelendiğinde \%38 inin aktivitelere katılım sağladığ1 \%62' sinin katılım sağlamadığ görülmektedir.

\section{Veri Toplama Araçları}

Araştırmada araştırmacı tarafından oluşturulan Kişisel Bilgi Formu, Şiddet Ĕ̆ilimi Ölçeği (ŞEÖ) ve Sosyal Bă̆lılık Ölçeği (SBÖ) kullanılmıştır.

\section{Kişisel Bilgi Formu}

Araştırmaya katılan öğrencilerin cinsiyet, müfredat dışı aktivitede yer alıp almadığı, müfredat dışı aktivitede bulunuyorsa hangi branşta katıldığı, sınıf düzeyi hakkında bilgi edinmek amacıyla kapalı uçlu sorulardan oluşturulmuştur.

\section{Şiddet Ĕ̆ilimi Ölçĕgi}

Göka, Bayat ve Türkçapar (1995) tarafından tasarlanan Şiddet Eğilim Ölçeği Milli Eğitim Bakanlığı adına yapılan bir araştırmada, Ortaöğretim düzeyinde eğitim görmekte olan öğrencilerin şiddet eğilim düzeylerini ölçmek maksadıyla geliştirilmiştir. Sonraki süreçte, kapsam geçerliliği sağlanarak ölçeğin ana düzeni yeniden desenlenmiş T.C. Başbakanlık Aile Araştırma Kurumu'nun “Aile İçinde ve Toplumsal Alanda Şiddet” konulu bilimsel çalışmada (1998) kullanılmıştır. Ölçekteki 20 soru dörtlü Likert tipi (1) "hiç uygun değil” den, ..., (4) "çok uygun” a değişen puanlama uygulanarak yapılmaktadır. Ölçekten elde edilecek en yüksek puan "80", en düşük puan "1" dir. Yüksek puan, öğrencilerin saldırganlık ve şiddet eğilimlerinin fazla olduğunu göstermektedir. Öğrencilerin ölçekten aldıkları puanlara göre, 120 arası puan "çok az", 21-40 arası puan "az", 41-60 arası puan "fazla" ve 61-80 arası puan "çok fazla" şiddet eğilimi olarak değerlendirilmiştir. Konu geçerliği yapılan araştırmada ölçeğin güvenirliğini kanıtlamak üzere iç tutarlılık kapsamında güvenirlik katsayısı farklı iki zaman diliminde 0.78 ve 0.87 bulunmuştur (Yakut, 2012). Çalışmamızda güvenirlik katsayısını ifade eden Cronbach Alpha değeri 0.91 bulunmuştur.

\section{Sosyal Bă̆lılık Ölçeği}

Lee ve Robbins (1995) tarafından geliştirilen Sosyal Bağlılık Ölçeği, kişilerin sosyal bağlılık düzeyini belirlemek maksadı ile tasarlanmıştır. Ölçeğin Türkiye uyarlaması Duru (2007) tarafından yapılmıştır. Ölçek 8 maddeden oluşmaktadır. Altılı ölçek tarzında geliştirilen ölçekte "Kesinlikle Katılmıyorum", 'Çoğunlukla Katılmıyorum', 'Katılmıyorum', 'Katılıyorum', 'Çoğunlukla Katılıyorum', 'Kesinlikle Katılıyorum' şıkları üzerinden bireylerin yaşadıkları kişilerarası olayları yorumlaması istenmektedir. Ölçek tek boyutlu olup konu geçerliliğini (geçerlik, güvenirlik) sağlamak için yapılan çalışmalarda iç tutarlılık katsayısı $\alpha=$ .91, iki hafta arayla test-tekrar test güvenirliği .96 olarak bulunmuştur (Duru, 2007). Çalışmamızda güvenirlik katsayısını ifade eden Cronbach Alpha değeri 0.87 bulunmuştur. 


\section{Araştırma Etiği}

Bu çalışma için, Eskişehir Teknik Üniversitesi Sosyal ve Beşeri Bilimler Bilimsel Araştırma ve Yayın Etiği Kurulu'nun E.2217 sayılı yazı ve 2/8 karar sayılı toplantısında etik onam alınmıştır.

\section{Verilerin Analizi}

Şiddet Eğilimi Ölçeği, Sosyal Bağlılık Ölçeği ve Kişisel Bilgi Formundan elde edilen veriler SPSS 22,0 programı kullanılarak kodlanmış ve gerekli analizler bu program ile yapılmıştır. Çalışmaya katılan örneklemdeki bireylere ilişkin kişisel bilgiler, ölçek toplam puanları ve faktör puanları frekans $(f)$ ve yüzde $(\%)$ değerleri belirlenerek verilmiştir. Ölçeklerden toplanan puanların çarpıklık ve basıklık değerleri incelenmiş olup, değerlerin $(+1)$ - $(-1)$ arasında olmasına bağlı olarak çalışmada parametrik testler kullanılmıştır. Yapılan analiz sonucunda şiddet eğilimi ölçeği ve sosyal bağlılık ölçeği için hesaplanan basıklık ve çarpıklık değerleri sırasıyla, $(-0,98)$ ile $(+0,52)$ ve $(-0,78)$ ile $(0,84)$ olarak bulunmuştur. Ölçeklerden alınan puanların karşılaştırılmasında bağımsız gruplarda $t$ testi analizi uygulanmıştır.

\section{BULGULAR}

$\mathrm{Bu}$ kısımda araştırma sonucunda toplanan bulgular çalışmanın genel amaç ve alt amacına uygun olarak verilmiştir.

\section{Müfredat dışı boş zaman aktivitelere katılımının ortaokul ögrencilerinin şiddet ĕgilimi} üzerine etkisi var midır?

Araştırmaya katılan öğrencilerin şiddet eğilimi düzeylerinin müfredat dışı boş zaman aktiviteleri katılımına göre farklılaşma durumunu ortaya koymak amacıyla bağımsız gruplar için $t$ testi kullanılmıştır. Yapılan analize ilişkin bulgular Tablo 2'de verilmiştir.

Tablo 2. Aktiviteye katılıma göre şiddet eğilimi düzeyi

\begin{tabular}{|c|c|c|c|c|c|c|c|}
\hline & Grup & $\mathbf{N}$ & Ortalama & $\begin{array}{c}\text { Standart } \\
\text { Sapma }\end{array}$ & $t$ & sd & $p$ \\
\hline \multirow{2}{*}{ Şiddet Eğilimi } & $\begin{array}{l}\text { Boş Zaman } \\
\text { Aktivitelerine } \\
\text { Katılmayan }\end{array}$ & 94 & 53,13 & 7,33 & \multirow{2}{*}{20,63} & \multirow{2}{*}{150} & \multirow{2}{*}{,001 } \\
\hline & $\begin{array}{l}\text { Boş Zaman } \\
\text { Aktivitelerine } \\
\text { Katılan }\end{array}$ & 58 & 31,00 & 4,57 & & & \\
\hline
\end{tabular}

Tablo 2 incelendiğinde boş zaman aktivitelerine katılan bireylerin şiddet eğilimi puan ortalamasının 31,00, boş zaman aktivitelerine katılmayan bireylerin şiddet eğilimi puan ortalamalarının 53,13 olduğu tespit edilmiştir. İki grubun puan ortalaması arasındaki farkın anlamlılı̆̆ını test etmek amacıyla hesaplanan $p$ değeri $(p<0,05)$ iki grubun puan ortalaması arasındaki farkın .05 düzeyinde anlamlı olduğunu göstermektedir. Bulgulardan elde edilen sonuçlara göre müfredat dışı boş zaman dışı boş zaman aktivitelerine katılan ve katılmayan 
ortaokul öğrencilerinin şiddet eğilimleri üzerinde anlamlı farklılık vardır $(p<0,05)$. Ortalamalar incelendiğinde boş zaman aktiviteleri yapan öğrencilerin şiddet eğilimleri aktivite yapmayanlara göre daha düşük çıkmıştır.

2. Müfredat dışı boş zaman aktiviteleri katılımının ortaokul öğrencilerinin sosyal bă̆lılık düzeyi üzerine etkisi var mıdır?

Araştırmaya katılan öğrencilerin sosyal bağl1lık düzeylerinin müfredat dışı boş zaman aktiviteleri katılımına göre farklılaşma durumunu ortaya koymak amacıyla bağımsız gruplar için t testi kullanılmıştır. Yapılan analize ilişkin bulgular Tablo 3'de verilmiştir.

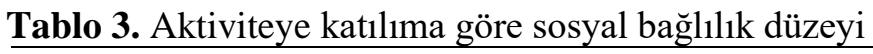

\begin{tabular}{|c|c|c|c|c|c|c|c|}
\hline \multirow{3}{*}{ Sosyal Bağlılık } & Grup & $\mathbf{N}$ & Ortalama & $\begin{array}{c}\text { Standart } \\
\text { Sapma }\end{array}$ & $t$ & $s d$ & $p$ \\
\hline & $\begin{array}{l}\text { Boş Zaman } \\
\text { Aktivitelerine } \\
\text { Katılmayan }\end{array}$ & 94 & 25,26 & 5,45 & \multirow{2}{*}{21,87} & \multirow{2}{*}{150} & \multirow{2}{*}{,000 } \\
\hline & $\begin{array}{l}\text { Boş Zaman } \\
\text { Aktivitelerine } \\
\text { Katılllan }\end{array}$ & 58 & 9,32 & 1,23 & & & \\
\hline
\end{tabular}

Tablo 3 incelendiğinde boş zaman aktivitelerine katılan bireylerin sosyal bağlılık puan ortalamasının 9,32, boş zaman aktivitelerine katılmayan bireylerin puan ortalamalarının 25,26 olduğu tespit edilmiştir. İki grubun puan ortalaması arasındaki farkın anlamlılığını test etmek amacıyla hesaplanan $p$ değeri $(\mathrm{p}<0,05)$ iki grubun puan ortalaması arasındaki farkın ,05 düzeyinde anlamlı olduğunu göstermektedir. Bulgulardan elde edilen sonuçlara göre müfredat dışı boş zaman dışı boş zaman aktivitelerine katılan ve katılmayan ortaokul öğrencilerinin sosyal bağlılıkları üzerinde anlamlı farklılık vardır $(p<0,05)$. Ortalamalar incelendiğinde boş zaman aktiviteleri yapan öğrencilerin sosyal bağlılık düzeyleri aktivite yapmayanlara göre daha düşük çıkmıştır.

\section{Müfredat dışı boş zaman aktiviteleri katılan ortaokul öğrencilerinin şiddet eğilimi düzeyinde} cinsiyete göre farklılık var midır?

Araştırma çerçevesinde müfredat dışı boş zaman aktivitesine katılan öğrencilerin şiddet eğilimi düzeylerinin cinsiyete göre farklılaşma durumunu ortaya koymak amacıyla bağımsız gruplar için $t$ testi kullanılmıştır. Yapılan analize ilişkin bulgular Tablo 4'de verilmiştir.

Tablo 4. Cinsiyete göre şiddet eğilimi

\begin{tabular}{|c|c|c|c|c|c|c|c|}
\hline \multirow{3}{*}{ Şiddet Eğilimi } & Grup & $\mathbf{N}$ & Ortalama & $\begin{array}{c}\text { Standart } \\
\text { Sapma }\end{array}$ & $t$ & $s d$ & $p$ \\
\hline & Kadın & 22 & 30,04 & 4,82 & \multirow{2}{*}{14,01} & \multirow{2}{*}{63} & \multirow{2}{*}{, 022} \\
\hline & Erkek & 36 & 31,58 & 4,38 & & & \\
\hline
\end{tabular}

Tablo 4 incelendiğinde boş zaman aktivitelerine katılan kadın bireylerin şiddet eğilimi puan ortalamasının 30,04, erkek puan ortalamalarının 31,58 olduğu tespit edilmiştir. İki grubun puan 
ortalaması arasındaki farkın anlamlılığ incelenciğinde $p$ değeri ,022 olarak tespit edilmiştir. Bulgulardan elde edilen sonuçlara göre müfredat dışı boş zaman dışı boş zaman aktivitelerine katılan ortaokul öğrencilerinin şiddet eğilimi puan ortalamaları arasında cinsiyete göre anlamlı farklılık vardır $(p<0,05)$. Ortalamalar incelendiğinde boş zaman aktiviteleri yapan öğrencilerin arasında erkek bireylerin şiddet eğilim puanlarının kadınlara göre daha yüksek çıkmıştır.

\section{Müfredat dışı boş zaman aktiviteleri katılan ortaokul öğrencilerinin sosyal bă̆lılık} düzeyinde cinsiyete göre farklılık var mıdır?

Araştırma çerçevesinde müfredat dışı boş zaman aktivitesine katılan öğrencilerin sosyal bağlılık düzeylerinin cinsiyete göre farklılaşma durumunu ortaya koymak maksadıyla bağımsız gruplar için $t$ testi kullanılmıştır. Yapılan analize ilişkin bulgular Tablo 5'de verilmiştir.

Tablo 5. Cinsiyete göre sosyal bağl1lık

\begin{tabular}{|c|c|c|c|c|c|c|c|}
\hline \multirow{3}{*}{ Sosyal Bağl1lık } & Grup & $\mathbf{N}$ & Ortalama & $\begin{array}{c}\text { Standart } \\
\text { Sapma }\end{array}$ & $t$ & sd & $p$ \\
\hline & Kadın & 22 & 9,04 & 1,29 & \multirow{2}{*}{16,76} & \multirow{2}{*}{63} & \multirow{2}{*}{,011 } \\
\hline & Erkek & 36 & 9,50 & 4,38 & & & \\
\hline
\end{tabular}

Tablo 5 incelendiğinde boş zaman aktivitelerine katılan kadın bireylerin sosyal bağlılık puan ortalamasının 9,04, erkek puan ortalamalarının 9,50 olduğu tespit edilmiştir. İki grubun puan ortalaması arasındaki farkın anlamlılığ incelenciğinde p değeri ,011 olarak tespit edilmiştir. Bulgulardan elde edilen sonuçlara göre müfredat dışı boş zaman dışı boş zaman aktivitelerine katılan ortaokul öğrencilerinin sosyal bağlılık puan ortalamaları arasında cinsiyete göre anlamlı farklılık vardır $(p<0,05)$. Ortalamalar incelendiğinde boş zaman aktiviteleri yapan öğrencilerin arasında erkek bireylerin sosyal bağlılık puanlarının kadınlara göre daha yüksek çıkmıştır.

\section{TARTIŞMA VE SONUÇ}

Boş zaman, yaşamımızın her döneminde ve farklı bir çok alanda sıklıkla kullandığımız, olumlu olarak yaşantımıza dahil edildiğinde gelişimimize büyük katkı sağlayan, geliştiren önemli bir araçtır. Günümüz şartlarında refah seviyesinin artması ile beraber bireylerin boş zaman olarak tanımladıkları zaman dilimi artış göstermiş, bu zaman dilimini iyi bir şekilde değerlendirebilmek için arayış içerisine girmiştir. Boş zaman artışı, okul içi dönemlerde de kendini belli etmiştir. Ortaokul düzeyi öğrenciler günün büyük çoğunluğunu okulda geçirdikleri için gerek müfredat içi gerek müfredat dışı boş zaman etkinliklerinin çok olması gelişimleri için önemli bir firsattır. İlgili literatür incelendiğinde boş zaman aktiviteleri, boş zaman aktiviteleri ve önemi, boş zamanın tarihsel gelişimi, boş zaman aktivitelerinin farklı gelişim alanlarına etkileri, müfredat içi ve müfredat dışı boş zaman aktivitelerinin diğer derslerde öğrenme sürecini nasıl etkilediğine dair bir çok çalışma bulunmaktadır. Boş zaman aktivitelerinin sosyal, duyuşsal ve sosyal beceriler kazanmalarında bir çok olumlu etki sağladığı sonucuna ulaşan çalışmalar vardır (Bloom, 2008; Efe, Öztürk, Koparan ve Şenışık, 2008; Oda, 2014; Süt, 2014). Woolf (2013) yaptı̆̆ 1 araştırmada ilkokul seviyesinde rekreatif akvitilerle desteklenerek bireylere uygulanan sosyo-duygusal yetenek geliştirme programının, öğrencilerin çeşitli bilişsel parametrelerle (duygu, özdenetim, öfke kontrolü) ilişsilerdeki 
sosyal becerilerin gelişiminde elde edilen pozitif sonuçları olduğunu ifade etmiştir. Taşkın (2019) ilkokul düzeyinde eğitim görmekte olan öğrencilerle yürüttüğü araştırmada, uyguladığ1 çeşitli rekreatif aktiviteler içeren 8 haftalık programın öğrencilerin öz saygısı üzerine önemli ölçüde etki ettiği sonucuna ulaşmıştır. Yıldız (2009) ortaöğretim düzeyi öğrencilerle yaptığı çalışmada aktivite yapmanın saldırganlık üzerine etkisini ortaya koymuş, spor yapan bireylerin saldırganlık düzeyinin diğer gruplara göre anlamlı düzeyde düşük olduğunu, saldırganlık seviyeleri çok çeşitli spor branşları (hentbol, basketbol, futbol masa tenisi vb.) arasında, atılganlık ve edilgenlik içeren saldırganlık puanlarının takım sporları ve kişisel olarak yapılan spor dalları arasında istatistiksel bir farklılık oluşturmadığını belirlemiştir $(p>0,05)$. Canan ve Ataoğlu (2010) yaptığı araştırmada düzenli katılım sağlanan sportif faaliyetlerin kaygı düzeyi üzerine pozitif etkisine ulaşmıştır. Ayrıca düzenli olarak spor yapan bireylerde depresyon ve problem çözme becerisi üzerine olumlu etkilerinin olduğu, takım sporlarının oluşan pozitif etkide önemli bir etken olduğu belirlenmiştir.

Çalışmamızın sonuçlarına göre müfredat dışı boş zaman aktivitelerine katılan öğrencilerin şiddet eğilimleri aktivite yapmayanlara göre daha düşük çıkmıştır. Son yıllarda yapılan çalışmalarların ulaştığı sonuçlara göre okullarda şiddetin hızlı bir şekilde yayıldığı, öğrencilerin şiddete başvurma düzeyi artış göstermiştir (Tuzgöl, 2000; Üstün, Yılmaz, Kırbaş, 2007; Haskan, Yıldırım, 2014). Varhan (2016) yaptığı araştırmada, ortaöğretim çağındaki öğrencilere 12 hafta boyunca düzenli olarak uygulanan sportif etkinlikler sonucunda öğrencilerin genel saldırganlık ve şiddet eğilim düzeyleri arasında anlamlı fark bulunmuş bu farklılık sportif etkinliklere katılan bireylerin lehine çıkmıştır. Bu çalışmaya paralel sonuç gösteren başka bir çalışmada Kırbaş, Taşmektepligil ve Üstün (2007) ortaöğretim düzeyi bireylerin şiddet eğilimini arttıran nedenleri ve azaltma yöntemleri araştırılmış ulaşılan sonuçlara göre boş zamanlarda müfredat dışı yapılan rekreatif faaliyetlere ve spora katılım sağlayan bireylerin şiddet eğilimlerinin daha düşük olduğu sonucuna ulaşılmıştır. Alanyazında rekreatif faaliyetlere katılım sağlamanın şiddet eğilimini düşüren bir etken olduğu sonucuna ulaşan çalışmalar olduğu gibi anlamlı farklılığın bulunamadığ çalışmalara da ulaşılmaktadır. Aydın, Ersoy ve Aktaş (2015) yaptığı çalışmada sportif faaliyetlere katılan ve katılmayan öğrenci bireylerin şiddet eğilimleri arasında anlamlı düzeyde farklılaşma olmadığını belirtmiştir. Çalışmada aktif spor yapan öğrencilerin şiddet eğilim düzeyleri daha düşük bulunmasına rağmen oluşan farklılık istatistiksel olarak anlamlı bulunmamıştır. Bu sonuçta öğrencilerin ortak sosyal ortamı paylaşmasının etkisinin olabileceği düşünülmektedir. Çalışmamızda cinsiyete göre şiddet eğilimi düzeylerine de bakılmıştır. Bulgulardan elde edilen sonuçlara göre müfredat dışı boş zaman dışı boş zaman aktivitelerine katılan ortaokul öğrencilerinin şiddet eğilimi puan ortalamaları arasında cinsiyete göre anlamlı farklılık vardır $(p<0.05)$. Ortalamalar incelendiğinde boş zaman aktiviteleri yapan öğrencilerin arasında erkek bireylerin şiddet eğilim puanlarının kadınlara göre daha yüksek çıkmıştır.

Çalışmamızla paralel sonuç gösteren Öztürk'ün (2019) yaptığı araştırma sonuçlarına göre; cinsiyet değişkenine bağlı olarak aktif olmayan sporcuların şiddet eğiliminde anlamlı farklılığa rastlanmıştır. Bu farklılık erkek katılımcıların şiddet eğilimlerinin daha yüksek olduğundan kaynaklanmaktadır. Aylık gelir değişkenine bağlı olarak aktif sporcuların şiddet eğiliminde anlamlı farklılığa rastlanmıştır. Bu farklılığa bağlı ortalama puanlar göstermektedir ki, aktif sporcuların aylık gelirleri düştükçe şiddet eğilimleri artış göstermektedir. Aktif olmayan 
sporcuların yaş ve spor yaşı değişkenleri ile saldırganlık düzeyleri arasında anlamlı düzeyde ters yönlü ilişki olduğu tespit edilmiştir. Alanyazın incelendiğinde çalışmamızla zıt yönde sonuca ulaşılan araştırmalar da bulunmaktadır. Aydın, Ersoy ve Aktaş (2015) yaptığı çalışmada öğrencilerin cinsiyet ve sportif faaliyetlere katılım durumlarına göre şiddet eğilimlerinde anlamlı farklılığa ulaşılamamışken, sınıf seviyesi ve sınıf içi başarı durumlarına göre anlamlı farklılıklar saptanmıştır.

Çalışmanın başka bir değişkeni olan boş zaman aktivitelerine katılıma göre sosyal bağlılık düzeyleri incelendiğinde müfredat dışı boş zaman aktivitelerine katılım sağlayan öğrencilerin sosyal bağl1lık düzeyleri aktivite yapmayanlara göre daha düşük çıkmıştır. Lee ve Robbins' in (1995) yaptığı çalışmada sosyal bağlılık düzeyi yüksek olan bireylerin sosyal ortamlarda daha rahat bir şekilde bulunabildiği, ihtiyaçlarını daha rahat yönettiği ve özsaygı seviyelerinin yüksek olduğu bilinmektedir. Çalışma sonuçlarından hareketle, boş zamanlarında spor yapan bireylerin sosyal bağlılıkları spor yapmayanlara göre daha yüksektir. Ayrıca, sınıf seviyelerine göre değişkenler incelendiğinde birinci sınıfta öğrenim görmekte olan öğrencilerin sosyal bağlılık dereceleri diğer sınıf seviyelerinin aldığı ortalama puanlara göre daha yüksek olduğu tespit edilmiştir (Lee ve Robbins, 1995). Hoye, Matthew ve Kevin'in (2015) yapmış olduğu 'spora katılım ve sosyal bağlılık' isimli çalışmada spor ve spor dışı aktivitelere katılım ile sosyal bağlılık arasındaki ilişki araştırılmıştır. Çalışmadan alınan sonuçlara göre spor organizasyonlarına katılımın sosyal bağlılığın bir yordayıcısı olduğu görülmüş spor organizasyonuna katılan bireylerin sosyal bağlılıkları anlamlı düzeyde yüksek çıkmıştır (Hoye, Matthw ve Kevin, 2015). Benzer şekilde literatür incelendiğinde genç bireylerin fiziksel aktivite sayesinde olumsuz duygu ve düşüncelerden uzaklaşması ve bu olumsuzluklardan korunmaları için vazgeçilmez bir değişken olduğunu göstermektedir (William ve Galliher, 2006).

Çalışmamızda sosyal bağlılık değişkenine göre ulaştığımız sonuçlarda ortalamalar incelendiğinde boş zaman aktiviteleri yapan öğrencilerin arasında erkek bireylerin sosyal bağlılık puanlarının kadınlara göre daha yüksek çıkmıştır. Alanyazın incelendiğinde, cinsiyet değişkenine göre sosyal bağlılık seviyesinde erkek bireylerin kadınlara göre daha yüksek sosyal bağlılığa sahip olduğu sonucuna ulaşan çalışmalara ulaşmak mümkündür (Wainwright ve Surtees, 2002). Savcı' nın (2017) ergenlerle yaptığı çalışmada bu bulguya paralel olarak sosyal zekâ, akran ilişkileri ve sosyal bağlılığın cinsiyete göre farklılaştığ1 görülmüştür. Araştırmanın bu bulgusu kadın ergen bireylerin erkek ergen bireylere göre kişilerarası zeka, akran ilişkileri ve sosyal bağlılık açısından daha avantajlı olduğunu göstermektedir. Bununla birlikte, sosyal bağlılık kapsamında cinsiyet farkının saptanmadığ 1 araştırmalar da mevcuttur (Chen ve Chung, 2007). Literatür taraması içinde sıkılganlık algısı ile yaşam doyumu arasında sınırlı sayıda çalışma bulunmasına karşın (Yaşartürk, Akyüz ve Karataş, 2017) kişilerin boş zaman doyum düzeyi ve yaşam doyum seviyeleri arasında pozitif seyir bulguları kısmen de olsa desteklemektedir (De Vos, 2018).

Sonuç olarak; elde edilen bulgulara göre müfredat dışı boş zaman aktivitesine katılan öğrencilerin şiddet eğilimi puanları katılmayan öğrencilere göre düşük çıkarken, cinsiyet değişkenine göre anlamlı farklılık bulunmuştur. Ayrıca müfredat boş zaman aktivitelerine katılan bireylerin sosyal bağlılık düzeyleri aktivite yapmayanlara göre daha düşük çıkarken, 
sosyal bağlılık değişkeninde cinsiyete göre istatistiksel anlamda anlamlı farklılık göstermektedir. Çalışma bulgularından hareketle okul içinde veya dışında ortaöğretim düzeyi öğrencilere müfredat dışı boş zaman aktivitelerle iç içe olma imkânı verilmelidir. Ayrıca gelişim dönemlerinden hareketle, farklı gelişim alanlarını destekleyecek şekilde aktivitelerle bireyler desteklenmeli, ortaöğretim düzeyinde müfredatta fiziksel aktivite sayılabilecek derslere yeterince yer verilmelidir.

\section{ÖNERILER}

*Ortaöğretim düzeyi bireylere daha çok boş zaman aktiviteleri imkânı tanınarak sosyal gelişimlerine katkı sağlanabilir.

*Öğrencilere boş zaman eğitimi verilerek boş zamanlarını değerlendirmede kullanabilecekleri aktiviteler hakkında bilgi sahibi olmaları sağlanabilir,

*Müfredat dışı boş zaman aktivitelerinin çocukların farklı gelişim alanlarına olan etkileri incelenebilir ve bu şekilde boş zaman aktivitelerinin çocuk üzerindeki fiziksel, bilişsel, duyşsal gelişim etkisi deneysel olarak ortaya konabilir.

*Ortaöğretim düzeyi öğrencilere bireysel oyunlar yerine grup oyunları oynatarak bu öğrencilerin sosyal gelişimleri, grup içi bağlılıkları arttırılırken, paylaşma duygusu ile şiddet eğilimi düzeyi azaltılabilir.

*Okul müfredatı gözden geçirilip beden eğitimi dersinin yanında boş zaman aktivitesi sayılabilecek ders sayısı ve ders saati sayıları arttırılıp ortaöğretim düzeyi öğrencilerde hem akademik başarının hem de sosyal becerilerinin gelişmesi sağlanabilir.

Çıkar Çatışması: Çalışma kapsamında herhangi bir kişisel ve finansal çıkar çatışması bulunmamaktadır.

Araştırmacıların Katkı Oranı Beyanı: Araştırma Dizaynı- MK; SM, İstatistik analiz- MK, Makalenin hazırlanması- MK; SM: 1. ve 2. yazarlar tarafından gerçekleştirilmiştir. Verilerin Toplanması- MK: 1. yazar tarafından gerçekleştirilmiştir.

\section{Etik Kurul İzni ile ilgili Bilgiler}

Kurul Adı: Eskişehir Teknik Üniversitesi Sosyal ve Beşeri Bilimler Bilimsel Araştırma ve Yayın Etiği Kurulu

Tarih: 18.01.2021

Sayı No: E-87914409-050.03.04-5621 
Kocamaz, M. ve Munusturlar, S. (2021). Müdredat dışı okul içi boş zaman aktivitelerine katılımının 10-14 yaş ortaokul öğrencilerin şiddet eğilimi ve sosyal bağl1lık düzeyleri üzerine etkisinin incelenmesi. Spor Bilimleri Araştırmaları Dergisi, $6(2), 335-348$.

\section{KAYNAKLAR}

Avcı, R. ve Güçray, S.S. (2010). Şiddet davranışı gösteren ve göstermeyen ergenlerin ailelerinin aile işlevleri, aile bireylerine ilişkin problemler, öfke ve öfke ifade tarzları açısından incelenmesi. Kuram ve Uygulamada Eğitim Bilimleri, 10(1), 45-76. https://doi.org/10.14527/kuey.2014.005

Aydın, P., Ersoy, A. ve Aktaş, N. (2015). Aktif spor yapan ve yapmayan 12-14 yaş ortaokul öğrencilerinin şiddet eğilimlerinin incelenmesi. Sportif Bakış: Spor ve Ĕgitim Bilimleri Dergisi,2(1), 1-9. Doi: $10.33468 /$ sbsebd.98

Başbakanlık Aile Araştırma Kurumu. (1998). Aile içinde ve toplumsal alanda şiddet. Bilim Serisi. Ankara: Başbakanlık Basımevi.

Beighle, A., Morgan, C.F., Le Masurier, G. \& Pangrazi, R.P. (2006). Children's physical activity during recess and outside of school. Journal of School Health, 76(10), 516-520. https://doi.org/10.1111/j.17461561.2006.00151.x

Bloom, G. (2008). Team building for youth sport. Journal of Physical Education, Recreation \& Dance, 79(9), 4447. https://doi.org/10.1080/07303084.2008.10598246

Burns, R.D., Brusseau, T.A. \& Hannon, J.C. (2015). Prediction of optimal daily step count achievement from segmented school physical activity. Advances in Public Health, 6(1), 26 https://doi.org/10.1155/2015/496248

Canan, F. ve Ataoğlu, A. (2010). Anksiyete, depresyon ve problem çözme becerisi algısı üzerine düzenli sporun etkisi. Anatolian Journal of Psychiatry, 11(38), 38-43.

Chen, L.J. \& Chung, S. K. (2007). Loneliness, social connectedness, and family income among undergraduate females and males in Taiwan. Social Behavior and Personality: An International Journal, 35(10), 13531364. https://doi.org/10.2224/sbp.2007.35.10.1353

De Vos, J. (2018). Analysing the effect of trip satisfaction on satisfaction with the leisure activity at the destination of the trip, in relationship with life satisfaction. Transportation, 46(3),623-645. https://doi.org/10.1007/s11116-017-9812-0

Duru, E. (2007). Sosyal bağlılık ölçeği’nin Türk kültürüne uyarlanması. Eğitim Araştırmaları Dergisi, 26(3), 8594.

Efe, M., Öztürk, F., Koparan, Ş., ve Şenışık, Y. (2008). 14-16 Yaş grubu erkeklerde voleybol çalışmalarının sosyal yetkinlik beklentisi ve atılganlı üzerine etkisi. Uludă̆ Üniversitesi Ĕ̆itim Fakültesi Dergisi, 21(1),6977.

Fairclough, S.J., \& Ridgers, N.D. (2010). Relationships between maturity status, physical activity and physical self- perceptions in primary school children. Journal of Sports Sciences, 28(1), 1-9. https://doi.org/10.1080/02640410903334780

Gözütök, D. (2008). Eğitim ve şiddet. Ankara: Gazi Kitabevi.

Hacıoğlu, N., Gökdeniz, A. ve Dinç, Y. (2003). Boş zaman \& rekreasyon yönetimi (Örnek Animasyon Uygulamaları). Editör: Yrd. Doç. Dr. Ayhan Gökdeniz. Ankara: Detay Yayıncılık.

Haskan, Ö. (2009). Ergenlerde şiddet eğilimi, yalnızlık ve sosyal destek. Yüksek Lisans Tezi, Hacettepe Üniversitesi Sosyal Bilimler Enstitüsü Eğitim Bilimleri Anabilim Dalı Psikolojik Danışma ve Rehberlik Bilim Dalı, Ankara.

Haskan, Ö. ve Yıldırım, İ. (2014). Ergenlerde şiddet eğilimi, yalnızlık ve sosyal destek. Hacettepe Üniversitesi Eğitim Fakültesi Dergisi, 29(1), 157-168.

Hoye, R., Matthew N. \& Kevin B. (2015). Involvement in sport and social connectedness. International Review for the Sociology of Sport, 50(1), 3-21. https://doi.org/10.1177/1012690212466076 
Kocamaz, M. ve Munusturlar, S. (2021). Müdredat dışı okul içi boş zaman aktivitelerine katılımının 10-14 yaş ortaokul öğrencilerin şiddet eğilimi ve sosyal bağl1lık düzeyleri üzerine etkisinin incelenmesi. Spor Bilimleri Araştırmaları Dergisi, $6(2), 335-348$.

Karasar, N. (2015). Bilimsel araştırma yöntemi. (205-207). Ankara: Nobel.

Kırbaş, Ş., Taşmektepligil, Y. ve Üstün, A. (2007). Ortaöğretimde gençleri şiddete yönelten nedenler ve şiddeti engellemede spor aktivitelerinin rolünün incelenmesi, Amasya ili örneği. Spormetre Beden Eğitimi ve Spor Bilimleri Dergisi, 5(4), 177-185. https://doi.org/10.1501/Sporm_0000000089

Lee, R. M. \& Robbins, S.B (1995). Measuring belongingness: The social connectedness and the social assurance scales. Journal of Counseling Psychology, 42(2), 232-241. https://doi.org/10.1037/0022-0167.42.2.232

McKenzie, T.L., Crespo, N.C., Baquero, B. \& Elder, J.P. (2010). Leisure-time physical activity in elementary schools: Analysis of contextual conditions. Journal of School Health, 80(10) 470-477. https://doi.org/10.1111/j.1746-1561.2010.00530.x

Mota, J., Silva, P., Santos, M.P., Ribeiro, J.C., Oliveira, J. \& Duarte, J.A. (2005). Physical activity and school recess time: Differences between the sexes and the relationship between children's playground physical activity and habitual physical activity. Journal of Sports Sciences, 23(3), 269-275. https://doi.org/10.1080/02640410410001730124

Oda, B. (2014). 11-13 Yaş grubundaki spor yapan ve yapmayan ögrencilerin iyimserlik ile saldırganlık düzeylerinin incelenmesi. Yüksek Lisans Tezi, Ondokuz Mayıs Üniversitesi Beden Eğitimi ve Spor Anabilim Dalı Sağlık Bilimleri Enstitüsü, Samsun.

Öztürk, Y. M. (2019). Aktif spor yapan ve yapmayan spor bilimleri fakültesi ögrrencilerinin sporda şiddet ĕ̌ilimi ve saldırganlık davranışlarına ilişkin görüşlerinin incelenmesi. Yüksek Lisans Tezi, Bartın Üniversitesi Eğitim Bilimleri Enstitüsü, Bartın.

Savcı, M. (2017). Ergenlerin sosyal zekâ, sosyal kaygl, akran ilişkileri, internet bă̆ımlılı̆̆ ve sosyal bă̆lılık düzeyleri arasındaki ilişkiler. Doktora Tezi, Dokuz Eylül Üniversitesi Eğitim Bilimleri Enstitüsü Eğitim Bilimleri Anabilim Dalı, İzmir.

Süt, M.A. (2014). Ortaöğretim öğrencilerinin spor yapma düzeylerine göre sosyal beceri özelliklerinin karşılaştırılması (Gaziantep İli Örneği). Yüksek Lisans Tezi, Ondokuz Mayıs Üniversitesi Sağlık Bilimleri Enstitüsü Beden Eğitimi ve Spor Anabilim Dalı, Samsun.

Şahin, H.N. (1999). Televizyonda şiddet ve çocuklarınız: Etkilenmemeleri için neler yapabilirsiniz. Türk Psikoloji Bülteni, 4(8), 76-82.

Taşkın, S. (2019). İlköğretim çă̆ındaki çocuklarda 8 haftalık rekreatif etkinliklerin benlik saygısı üzerine etkisinin incelenmesi. Yüksek Lisans Tezi, Batman Üniversitesi Sosyal Bilimler Enstitüsü, Batman.

Troiano, R.P., Berrigan, D., Dodd, K.W., Masse, L.C., Tilert, T. \& McDowell, M. (2008). Physical activity in the United States measured by accelerometer. Medicine Sciens Sports Exercise 40(5), 181-188. DOI: 10.1249/mss.0b013e31817057da

Taras, H. (2005). Physical activity and student performance at school. Journal of School Health, 75(10), 214-218. https://doi.org/10.1111/j.1746-1561.2005.tb06675.x

Trudeau, F. \& Shephard, R.J. (2010). Relationships of physical activity to brain health and the academic performance of school children. American Journal of Lifestyle Medicine, 4(10), 138-150. https://doi.org/10.1177/1559827609351133

Tuzgöl, M. (2000). Ana-Baba tutumları farklı lise öğrencilerinin saldırganlık düzeylerinin çeşitli değişkenler açısından incelenmesi. Türk Psikolojik Danışma ve Rehberlik Dergisi, 2(14), 39-48. https://doi.org/10.17066/tpdrd.1001698

Üstün, A., Yılmaz, M. ve Kırbaş, Ş. (2007). Gençleri şiddete yönelten nedenler. İçinde, Solak. A (Ed), Okullarda şiddet ve çocuk suçlululuğu. Ankara: Hegem Yayınları.

Varhan, Ş. (2016). Orta ögretim düzeyindeki tek ebeveynli sporcu ögrencilerin 12 haftalı sportif etkinliklerinin saldırganlık ve şiddet eğilimi düzeylerine etkilerinin incelenmesi. Yüksek Lisans Tezi, Kütahya Dumlupınar Üniversitesi/Sağlık Bilimleri Enstitüsü, Kütahya. 
Kocamaz, M. ve Munusturlar, S. (2021). Müdredat dışı okul içi boş zaman aktivitelerine katılımının 10-14 yaş ortaokul öğrencilerin şiddet eğilimi ve sosyal bağlılık düzeyleri üzerine etkisinin incelenmesi. Spor Bilimleri Araştırmaları Dergisi, 6(2), 335-348.

Yakut, S. (2012). Lise öğrencilerinde dindarlık-şiddet eğilimi ilişkisi. Yüksek Lisans Tezi, Süleyman Demirel Üniversitesi Sosyal Bilimler Enstitüsü Felsefe ve Din Bilimleri Anabilim Dalı, Isparta.

Yaşartürk, F., Akyüz, H. ve Karataş, İ. (2017). Examination of university students' levels of leisure boredom perception and life satisfaction towards recreative activities. International Journal of Cultural and Social Studies, 3(2), 239-252. doi:10.11114/jets.v7i3.3988

Yıldız, S. (2009). Spor yapan ve spor yapmayan orta ögretim ögrrencilerinin saldırganlık düzeylerinin incelenmesi. Yüksek Lisans Tezi, Selçuk Üniversitesi Sağlık Bilimleri Enstitüsü, Konya.

Wainwright, N. \& Surtees, P. (2002). Childhood adversity, gender, and depression over the life-course. Journal of Affective Disorders, 72(1), 33-45. https://doi.org/10.1016/S0165-0327(01)00420-7

Williams, K.L. \& Galliher, R.V. (2006). Preticting depression and self-esteem from social connectedness, support, and competence. Journal of Social and Clinical Psychology,25(8), 855-874. https://doi.org/10.1521/jscp.2006.25.8.855

Woolf, A. M. (2013). Social and emotional aspects of learning: Teaching and learning or playing and becoming. Pastoral Care in Education, An International Journal of Personal, Social and Emotional Development, 31(1), 28-42. https://doi.org/10.1080/02643944.2012.702782

Bu eser Creative Commons Atıf-Gayri Ticari 4.0 Uluslararası Lisansı ile lisanslanmıştır. 